\title{
Development and in vitro evaluation of tablets based on the antichagasic benznidazole
}

\author{
José Lamartine Soares Sobrinho', Luciana Neiva Antunes Lima', Diego Cavalcanti Perrelli', \\ Jeckson Luiz da Silva ${ }^{1}$, Flávia Patrícia Morais de Medeiros ${ }^{1,2}$, \\ Mônica Felts de La Roca Soares ${ }^{1}$, Pedro José Rolim Neto ${ }^{1 *}$ \\ 'Laboratory of Medicine Technology (LTM), Pharmaceutical Sciences Department, \\ Federal University of Pernambuco, ${ }^{2}$ State of Pernambuco Pharmaceutical Laboratory (LAFEPE)
}

*Correspondence:

P. J. Rolim Neto

Laboratório de Tecnologia dos

Medicamentos - LTM

Departamento de Ciências

Farmacêuticas

Universidade Federal de Pernambuco Av. Prof. Arthur de Sá, S/N - Cidade

Universitária

50740-521 - Recife - PE, Brasil

E-mail: pedro.rolim@pq.cnpq.br
This work aimed to verify the interferences caused by the use of excipients for immediate release tablets based on benznidazole obtained by direct compression and the accomplishment of a comparative study between the tablets developed and the reference medicine Rochagan ${ }^{T M}$, obtained by wet granulation. Seven smallscale batches (SSB) were developed and aspects such as compressibility, powder flow, mean weight, friability, disintegration, hardness, assay, content uniformity, kinetic of release in vitro (dissolution) and drug/excipients physical-chemical compatibility were evaluated. Based on the obtained results it can be verified that the analyzed powders presented adequated characteristics for the direct compression process, beyond the inexistent evidence of a physical-chemical interaction between the drug and the tested excipients. The tablets obtained from SSB I and III were chosen for the comparative study with the reference medicine, demonstrating similarity with the statistically treated obtained results, becoming an alternative option of a medicine product for the treatment of Chagas'disease with reduced cost and satisfactory quality.

\section{INTRODUCTION}

In Latin America the morbidity and mortality rates associated with Chagas' disease possess a greater magnitude than that reached with malaria, schistosomiasis and leishmaniasis, constituting one of the biggest public health problems of developing nations (Lamas et al., 2006). Less than $1 \%$ of 1300 new medicines developed in the last 25 years have been developed for the neglected diseases (MSF, 2001). Benznidazole is not only the drug of choice for Chagas' disease treatment, but nowadays it is also the only one available on the world market (Coura, Castro, 2002; Schofield, Jannin, Salvatella, 2006).

Benznidazole (BNZ) was introduced in Chagas' disease therapy in 1972 by the Pharmaceutical Company Roche $^{\mathrm{TM}}$ with the commercial name Rochagan ${ }^{\mathrm{TM}}$. On march $3^{\text {rd }}, 2003$, this company donates your patent rights of the product explore to the Brazilian Government, that passes the privilege to produce this medicine for the State of Pernambuco Pharmaceutical Laboratory (LAFEPE ${ }^{\mathrm{TM}}$ ) 
and this company receive the responsibility to be the world medicine producer for this disease therapy.

Rochagan ${ }^{\mathrm{TM}}$ manufacturing technique consists by a wet granulation technique, which possess in the formulation, corn starch and talc powder, as the main excipients. This formulation was developed over 30 years ago and the LAFEPE ${ }^{\mathrm{TM}}$ researchers in partnership with the LTM-UFPE researchers decided to reformulate this medicine, with the purpose of improve this product, giving it a low manufactory cost and adding it a technological valor and simplicity.

The development of pharmaceuticals forms has diverse stages, such as the pre-formulation and the formulation studies. The direct compression method offers many advantages over the conventional technique, the method by wet granulation, such as simplicity, economy, and reduction of manufacture stages and increase of stability (Lin, Lin, Li, 2001; Wanczinski et al., 2002). The adequate use of excipients has been producing great advances in tablets obtained by the direct compression process (Mccormik, 2005).

The majority of drugs, including benznidazole, do not present flow properties and high compressibility necessary for direct compression, requiring addition of excipients, which strengthens the weak linkings between particles, facilitating the cohesion of the material and, consequently, the compression (Maarschalk et al., 1999). However, with the advance of new available excipients to the pharmaceutical market, the use of the direct compression technique for many drugs of inadequate flow characteristics is becoming possible.

The currently available excipients contribute, mainly, to making the cohesion between particles, the flowing powder of the product in the machines used and the disintegration of compressed tablets possible, without the previous necessity of granulation, reducing the manufacturing time and, consequently, reducing the product's final cost (Baracat et al., 2001).

Based on the above, the objective of this work was to verify the possible interferences between the excipients used in the direct compression process to manufacture benznidazole tablets, as well as carrying out a comparative study between the developed medicines by direct compression and the reference product obtained by wet granulation.

\section{MATERIAL AND METHODS}

\section{Raw-Materials}

The raw-materials used were: Microcrystalline Cellulose (MC) 102 (Compecel $^{\mathrm{TM}}$, batch 70337), MC 250 (Blanver $^{\mathrm{TM}}$, batch 12155/06), Anhydrous Lactose (Pharma Nostra $^{\mathrm{TM}}$, batch 10301215), Spray-dried Lactose (DMV Fonterra Excipient ${ }^{\mathrm{TM}}$, batch BQ030012) and Magnesium Stearate (Valdequímica ${ }^{\mathrm{TM}}$, batch 1478) as excipients; Benznidazole as drug (Roche Pharmaceutical, batch BS0204002) and as final product the developed tablets by direct compression and the reference medicine Rochagan ${ }^{\mathrm{TM}}$ from Roche ${ }^{\mathrm{TM}}$, obtained by wet granulation, as well as the working standard, for the analytical methods, supplied for the same industry.

\section{Methods}

Seven small-scale batches (SSB) of $1 \mathrm{~kg}$ were obtained using the excipients cited above (Table 1). The preparation technique of the developed product consists in weigh out all raw material separately in a Denver Instrument APX-3202 precision balance and after that passes to a 30 mesh metal screen to prevent grume that could influences the homogenity. The mix process has two steps; firs step was constitution the mix of the drug with diluents for 10 minutes in a Lawes twingshell blender of $1 \mathrm{~kg}$ capacity and the second step was to add a diluent to this mixture in the same equipment for 2 minutes. To finish the process the mixture powder was compressed in a compression machine (Neuberger, $\mathrm{MN}-16$ ), with 16 punches of 9 mm diameter.

Some aspects were observed such as: compressibility (Hausner factor and Carr index), powder flow, grain size

TABLE I - Formulations of the SSB

\begin{tabular}{lccccccc}
\hline Components (\%) & SSBI & SSB II & SSB III & SSB IV & SSB V & SSB VI & SSB VII \\
\hline Benznidazole & 28.57 & 28.57 & 28.57 & 28.57 & 28.57 & 28.57 & 28.57 \\
MC 250 & 70.43 & - & 35.21 & - & - & 35.21 & 35.21 \\
MC 102 & - & 70.43 & 35.21 & - & - & - & - \\
Anhydrous Lactose & - & - & - & 70.43 & - & 35.21 & - \\
Spray-dried Lactose & - & - & - & - & 70.43 & - & 35.21 \\
Magnesium Stearate & 1.0 & 1.0 & 1.0 & 1.0 & 1.0 & 1.0 & 1.0 \\
\hline
\end{tabular}


distribution, mean weight, friability, disintegration, hardness, assay, content uniformity, kinetic of release in vitro (dissolution) and the drug/excipient physical-chemical compatibility.

\section{Determination of angle of repose and draining speed}

The evaluation of the angle of repose $( \pm)$ and speed flow was determined in accordance with the United States Pharmacopeia (USP, 2006; Viana et al., 2006).

\section{Hausner factor and Carr index}

The evaluation of the Hausner factor and Carr index was determined in accordance with Rolim Neto (1992). The Hausner factor was determined through the relation between the apparent and compact densities, determined by a Tap Density Tester (Vankel, 230).

The Carr index or Compressibility index was determined by the quotient between the apparent and compact densities in percentage. The compressibility percentage indirectly gives an idea of the cohesion, size uniformity and surface area of powders or their mixtures.

\section{Grain size distribution}

The determination of the grain size distribution was carried out in accordance with the method described in the Brazilian Pharmacopeia (1988). A sample of $30 \mathrm{~g}$ was placed on the upper sieve and it was submitted to sift for 30 minutes.

\section{Study of drug/excipient physical-chemical compatibility}

Analyses were carried out to verify the possible physical-chemical interactions between the drug and excipients of the two best developed formulations. The DTA thermogram of benznidazole, excipients and respective binary mixture was obtained by a DTA- 50 cell Shimadzu using alumina crucibles with about $8.0 \mathrm{mg}$ of samples, under a flow dynamic nitrogen atmosphere at $50 \mathrm{~mL}$. $\mathrm{min}^{-1}$ and heating rate of $10^{\circ} \mathrm{C} \cdot \mathrm{min}^{-1}$ until $500{ }^{\circ} \mathrm{C}$ and $30^{\circ} \mathrm{C} \cdot \mathrm{min}^{-1}$ until $900^{\circ} \mathrm{C}$. The DTA cell was calibrated initially with indium (m.p. $156.6{ }^{\circ} \mathrm{C} ; \Delta \mathrm{H}_{\text {fus }}=28.54 \mathrm{~J} . \mathrm{g}^{-1}$ ) and then zinc (m.p. $\left.419.6^{\circ} \mathrm{C}\right)$ (Bazzo, Silva, 2005).

\section{Evaluation of developed tablets and reference medicine}

Mean Weight: the method used is described in the Brazilian Pharmacopeia (1988), with tolerance range of
$5 \%$ for tablets with mean weight above $350 \mathrm{mg}$. Hardness: the determination of tablet hardness was carried out using a Vankel ${ }^{\circledR}$ K 200 hardness tester. The minimum hardness established for tablets is $4 \mathrm{Kgf}$ in accordance with the Brazilian Pharmacopeia (1988). Friability: the friability of the tablets was determined in accordance with Brazilian Pharmacopeia (1988) and the acceptable value must be inferior of $1.5 \%$ of the established weight. Disintegration: the disintegration test was carried out by the method described in the Brazilian Pharmacopeia (1988), by a Nova Ética ${ }^{\circledR}$ disintegrator, with the maximum time specification of 15 minutes. Assay: a spectrophotometer method described by Soares Sobrinho et al. (2006) was developed and validated. The method uses a wavelength of $324 \mathrm{~nm}$ for BNZ, water as blank and a final solute concentration of $20 \mu \mathrm{g} / \mathrm{mL}$. Dissolution: according to a method supplied by the pharmaceutical company LAFEPE ${ }^{\mathrm{TM}}$, that uses artificial non enzymatic gastric juice as dissolution medium $(\mathrm{HCl} 0.1 \mathrm{M})$, medium volume of $1000 \mathrm{~mL}$ at $37^{\circ} \mathrm{C} \pm 0,5^{\circ} \mathrm{C}$; apparatus 1 (basket) and rotation of $100 \mathrm{rpm}$, carried out by a Varian ${ }^{\mathrm{TM}}$ Dissolutor, Model VK-7000, 7010 and 750D with automatic collector, model VK-8000. The quantification of the BNZ dissolution percent was carried out in Micronal B582 Spectrophotometer in a $324 \mathrm{~nm}$ wavelength and artificial non enzymatic gastric juice as the blank. The results may present according specification method: Qe" $60 \%$ of drug dissolved in 60 minutes and Qe" $80 \%$ of drug dissolved in 120 minutes.

\section{Kinetic of in vitro release}

The tablets kinetics of release from SSBI, SSBIII and reference medicine, Rochagan ${ }^{\mathrm{TM}}$, follows the method used for dissolution tests, being the times of collection 10, 30, 45,60 and 120 minutes. The results were used to calculate the dissolution efficacy (DE) and later compared with the variance analysis (ANOVA) (Aguiar et al., 2005; Anderson et al., 1998; Khan, 1975; Khan, Rhodes, 1972).

\section{RESULTS AND DISCUSSION}

\section{Quality Control of the SSB developed}

The grain size distribution (Figure 1) showed a high percentage of fine powder in the drug analysis, a factor that characterizes a powder with poor rheological properties of flow. It can also be observed that the mixture of these excipients with the drug improves significantly the grain size distribution of the mixture giving a flow to the powders.

Generally the small-scale batches presented very similar rheological advantages in comparison with the 
isolated drug material, a fact that can be correlated with the angle of repose (with the exception of SSB V) and flow speed (Table II). SSB I, III, IV and VII resulted in the best grain size distribution from the technological point of view, presenting themselves as more homogeneous.

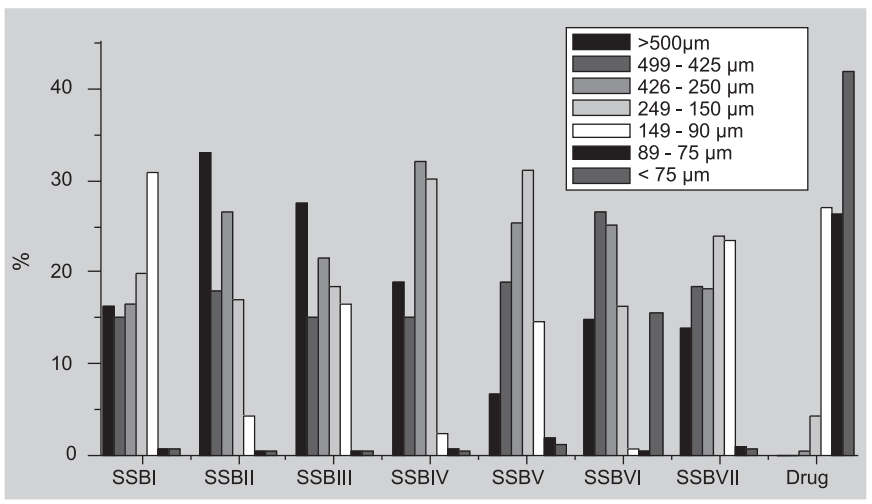

FIGURE 1 - Grain size distribution of benznidazole drug and respective mixtures of powders composing the smallscale batches obtained.

The flow characteristics (angle of repose and flow speed) and the compressibility aptitude (Hausner factor and Carr index) demonstrated that some of the seven tested formulations had not obtained results in the range of the specifications in accordance with the United States Pharmacopeia (2006), specifically the SSB II, IV and VII.

However, due to the small differences in the obtained results the compression of all the previously formulated SSB was undertaken. The first evaluated aspect after the compression process was the mean weight of the tablets, also taking into consideration the standard deviation of each obtained batch. In this stage of choice an ideal formulation, it was noted that the majority of the
SSB presented results inside the specifications $( \pm 5 \%)$, however batches II, IV, V, VI and VII presented a high standard deviation.

For the rest of physical-chemical tests there were not differences in results between the tested SSB. In the friability analyses, disintegration, hardness, assay, content uniformity and dissolution test the SSB gave results in the range of the specifications with the exception of LB IV in the hardness test (Table II). Based on the obtained results two formulations (LB I and III) were chosen for carrying out the drug/excipient interaction study and posterior kinetic of release, to compare the results with the reference medicine Rochagan ${ }^{\mathrm{TM}}$ from Roche Pharmaceutical.

\section{Drug/excipients physical-chemical compatibility study}

DTA curves of benznidazole show an endothermic process characteristic of melting in the range of 187.68 to $198.88^{\circ} \mathrm{C}$, with melting peak at $191.1^{\circ} \mathrm{C}$ and enthalpy

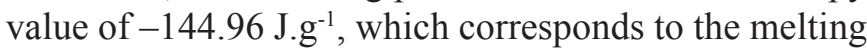
range the literature (Farmacopéia Brasileira, 1988) and exothermic process characteristic of decomposition at the range of 259.94 to $285.16^{\circ} \mathrm{C}$, with decomposition peak in $278.62{ }^{\circ} \mathrm{C}$ and enthalpy value of $975.77 \mathrm{J.g}^{-1}$ (Figure 2).

The results obtained with the DTA technique showed that the association of benznidazole with the tested excipients does not show evidence of any significant physical interaction, due to the values of reaction and fusion enthalpy, when the value of the melting peak of benznidazole remains uncharged for all the binary mixtures around $191{ }^{\circ} \mathrm{C}$ (Table III e Figure 2). Also they do not show evidence of any significant chemical interaction, the discrete displacement evidenced retarding the decomposition peak of the drug in the binary mixtures thermogram and the reduction of decomposition enthalpy

TABLE II - Quality control of the SSB obtained

\begin{tabular}{|c|c|c|c|c|c|c|c|c|}
\hline Parameters & Specifications & SSB I & SSB II & SSB III & SSB IV & SSB V & SSBVI & SSB VII \\
\hline Friability & $<1.5 \%$ & 0.11 & 0.22 & 0.14 & 0.5 & 0.91 & 0.18 & 0.25 \\
\hline Hardness & $>4.0 \mathrm{kgf}$ & 4.65 & 5.28 & 6.16 & 3.25 & 4.85 & 5.28 & 4.76 \\
\hline Assay & $95-105 \%$ & 99.15 & 98.57 & 100.07 & & & 101.07 & 99.02 \\
\hline Angle of repose & $<35^{\circ}$ & 34.03 & 32.73 & 29.91 & 37.09 & 34.05 & 32.60 & 31.20 \\
\hline Flow speed & $<10 \mathrm{~s}$ & 5 & 9 & 6 & 5 & 5 & 5 & 5 \\
\hline Hausner factor & $<1.25$ & 1.15 & 1.48 & 1.1 & 1.13 & 1.2 & 1.22 & 1.35 \\
\hline Carr index & $<25 \%$ & 18 & 22 & 9 & 11 & 16 & 19 & 26 \\
\hline
\end{tabular}


value can be explained at the moment benznidazole melts and the microcrystalline cellulose continues to be solid and incorporates it. Therefore, the cellulosis does not show a process of fusing and its decomposition occurs at approximately $370^{\circ} \mathrm{C}$. Generally chemical interactions reactivity, characterized for the displacement of the decomposition peak, potentially occur when two compounds are in liquid form.

The results prove that the pharmaceutical form tablets of immediate release based on benznidazole is possible, using the tested excipients, with stability, a requirement that could be confirmed and correlated in the stability test following the international guidelines for pharmaceutical forms. This makes the continuity of the pharmaceutics development in a rational form possible.

The magnesium stearate, even though it was part of the two selected formulations, was not tested because of the possibility of physical-chemistry interactions due to the small percentage of the excipient in the formulation ( $1 \%)$.
After the confirmation that there was no physical or chemical interaction between the drug and the two tested excipients, selected by the best two small-scale batch (SSB I and III), the dissolution profile tests of the elected SSB were carried out together with the reference medicine, making it possible to observe in accordance with the dissolution efficacy (DE) of SSB I (58.02), SSB III (56.11) and the reference medicine (54.89). The similarity between the studied profiles (Figure 2), the variance analysis (ANOVA) demonstrated with level of $5 \%$ of probability an insignificant value of $F$, and a value of $p$ bigger than the probability level. Therefore, the averages showed to be statistically equal (calculated $\mathrm{F}=3.9255$ and priced $\mathrm{F}=4.2564$ ).

The BNZ drug is characterized by the manufacturer $\left(\right.$ Roche $^{\mathrm{TM}}$ ) as poorly soluble in water and very permeable, however the data available in the scientific papers published are confuse and dubious related to the drug solubility, because some of them classified the drug as soluble in water (Lindenberg, Kopp, Dressman, 2004;

TABLE III - Calorimetric parameters of benznidazole and binary mixtures

\begin{tabular}{lcccc}
\hline Sample & $\begin{array}{c}\text { DTAfusion peak } \\
\left({ }^{\circ} \mathrm{C}\right)\end{array}$ & $\begin{array}{c}\text { DTA } \Delta \text { Hfusion } \\
(\mathrm{J} / \mathrm{g})\end{array}$ & $\begin{array}{c}\text { DTAdecomposition peak } \\
\left({ }^{\circ} \mathrm{C}\right)\end{array}$ & $\begin{array}{c}\text { DTA } \Delta \text { HDecomposition } \\
(\mathrm{J} / \mathrm{g})\end{array}$ \\
\hline BNZ & 191.10 & -144.96 & 278.62 & 975.77 \\
BNZ:MC 102 & 192.90 & -65.21 & 291.19 & 324.47 \\
BNZ:MC 250 & 192.73 & -65.45 & 287.95 & 379.63 \\
\hline
\end{tabular}

Kinetic of release in vitro (dissolution)

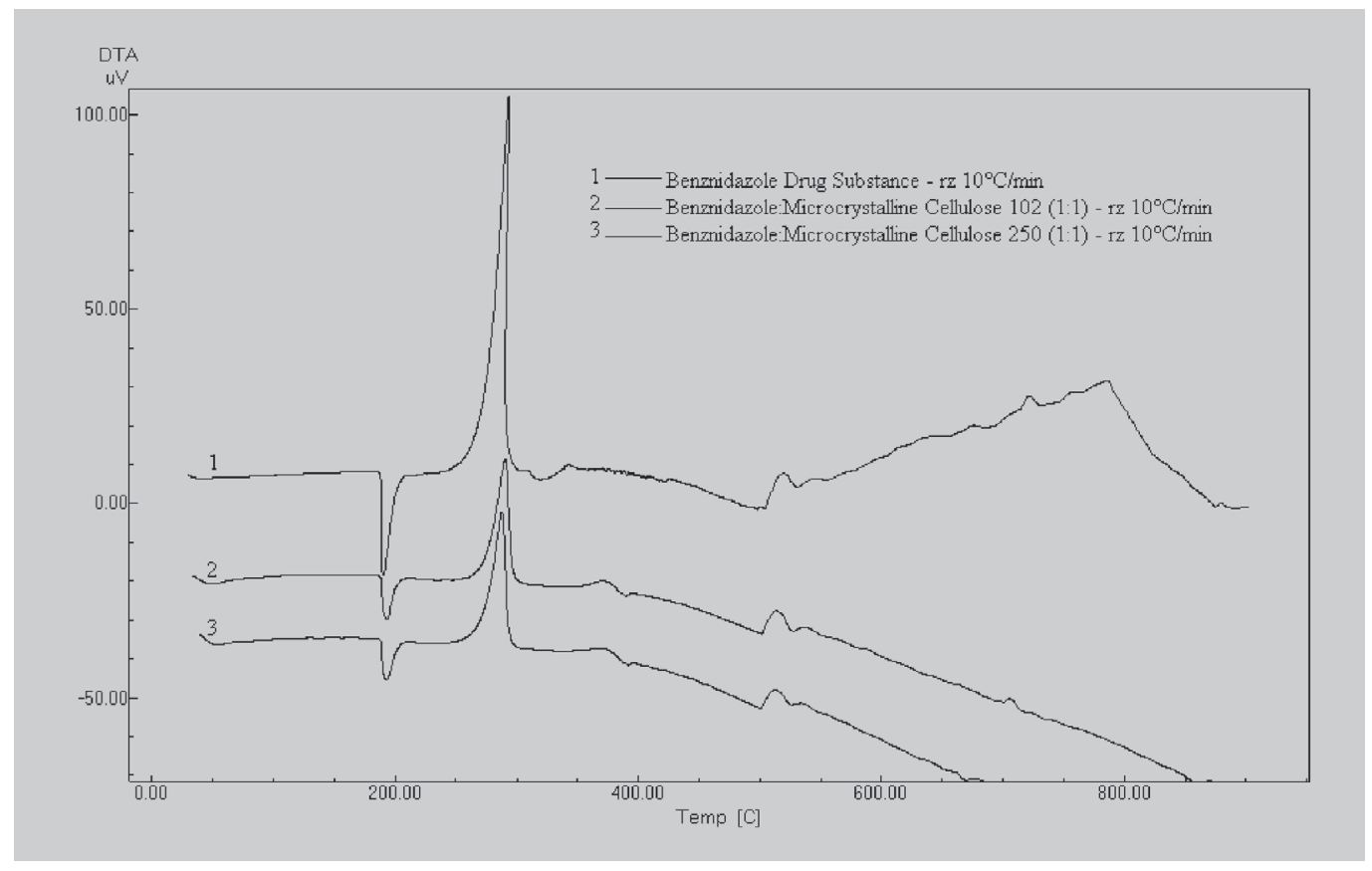

FIGURE 2 - DTA curves of Benznidazole drug substance and excipients. 
Kasim et al., 2004). For this reason it is not possible to propose a correlation in vivo-in vitro using the published drug data, but it could be proposed for a drug with this characteristics that the dissolution step will be the critical factor in the drug biodisponibility. Therefore, the pharmacokinetics profile of the developed medicine could be similar to the commercialized one, once the in vitro profile of dissolution is considered statistically equal.

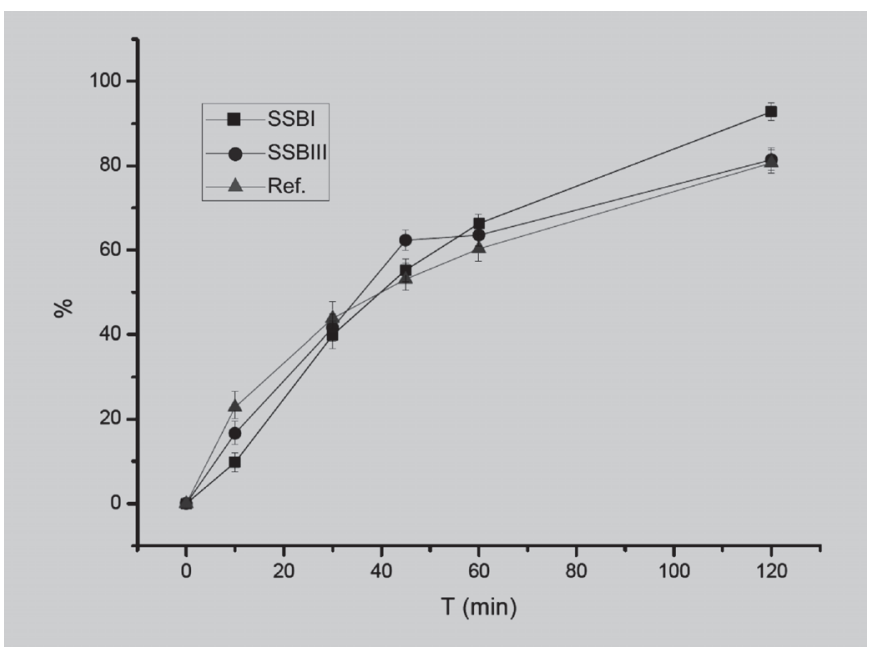

FIGURE 3 - Kinetics of in vitro release.

\section{CONCLUSION}

The presented results comprised the characterization of the flow and compressibility properties of seven smallscale batches mixtures and drug/excipient physicalchemical compatibility, as well as the confirmation of quality of the two batches chosen from the in vitro similarity with the reference medicine kinetics release.

Based on the the results the developed formulations are considered alternatives for the production of immediate release tablet based on benznidazole, using the technology of direct compression. It is a fast process, of practical attainment and production reduced cost, and the developed product has the quality demanded for oral solid pharmaceutical form.

\section{RESUMO}

\section{Desenvolvimento e avaliação in vitro de comprimidos a base do antichagásico benznidazol}

O trabalho teve como objetivo a verificação das possíveis interferências dos excipientes utilizados na obtenção do comprimido de liberação imediata à base de benznidazol por meio do processo de compressão direta e realização de estudo comparativo entre os comprimidos obtidos e o medicamento de referência Rochagan ${ }^{\circledR}$, obtido por meio da granulação por via úmida. Sete lotes de bancada (LB) foram produzidos e aspectos, tais como compressibilidade, fluxo do pós, peso médio, friabilidade, desintegração, dureza, teor, dissolução, uniformidade de conteúdo, cinética de liberação in vitro (dissolução) e compatibilidade físico-química fármaco/excipiente foram avaliados. Diante dos resultados obtidos pode-se verificar que os pós analisados apresentaram características adequadas para o processo da compressão direta, além da comprovação da não existência de interação de natureza físico-química entre ofármaco e os excipientes testados. Os comprimidos obtidos a partir do LB I e III foram escolhidos para o estudo comparativo frente ao medicamento de referência, demonstrando semelhança com os resultados observados, tratados estatisticamente. Torna-se, assim, uma alternativa para a produção de medicamento destinado ao tratamento da doença de Chagas com um custo reduzido e qualidade satisfatória.

UNITERMOS: Benznidazol. Excipientes. Compressão Direta. Comprimido. Doença de Chagas.

\section{ACKNOWLEDGEMENTS}

To CAPES, CNPq and LAFEPE for the financial support for accomplishment of the research.

\section{REFERENCES}

AGUIAR, G.; FARIA, L.G.; FERRAZ, H.G.; SERRA, C.H.R.; PORTA, V. Avaliação biofarmacotécnica in vitro de formas farmacêuticas sólidas contendo doxiciclina. Rev. Bras. Cienc. Farm., v.41, n.4, p.451-458, 2005.

ANDERSON, N.H.; BAUER, M.; BOUSSAC, N.; KHANMALEK, R.; MUNDEN, P.; SARDARO, M. An evaluation of fit factors and dissolution efficiency for the comparison of in vitro dissolution profiles. J. Pharm. Biomed. Anal., v.17, n.4-5, p.811-822, 1998.

BARACAT, M.M.; NERY, M.M.F.; GOUVEIA, E.F.; MENEGUELLI, L.; HIZUKA, S.M.; MAMPRIM, C.M. Estudo comparativo de excipientes em diferentes técnicas de preparação de comprimidos de cloridrato de propranolol. Semina: Ci. Biol. Saúde, v.22, n.1, p.19-24, 2001. 
BAZZO, G.C; SILVA, M.A.S. Estudo termoanalítico de comprimidos revestidos contendo captopril através de termogravimetria (TG) e calorimetria exploratória diferencial (DSC). Rev. Bras. Cienc. Farm., v.41, n.3, p.315-322, 2005.

COURA, J.R.; CASTRO, S.L. ACritical Review on Chagas' disease Chemotherapy. Mem. Inst. Oswaldo Cruz, v.97, n.1, p.3-24, 2002.

FARMACOPÉIA Brasileira. 4.ed. São Paulo: Atheneu, 1988. pt.1, v.1.5 a v.1.5-4.

KASIM, N.A.; WHITEHOUSE, M.; RAMACHANDRAN, C.; BERMEJO, M. Molecular Properties of WHO Essential Drugs and Provisional Biopharmaceutical Classification. Mol. Pharm., v.1, n.1, p.85-96, 2004.

KHAN, K.A. The concept of dissolution efficiency. J. Pharm. Pharmacol., v.27, p.48-49, 1975.

KHAN, K.A.; RHODES, C.T. Effect of compaction pressure on the dissolution efficiency of some direct compression systems. Pharm. Acta Helv., v.47, p.594-607, 1972.

LAMAS, M.C.; VILLAGGI, L.; NOCITO, I.; BASSANI, G.; LEONARDI, D.; PASCUTTI, F.; SERRA, E.; SALOMÓN, C.J. Development of parenteral formulations and evaluations of the biological activity of the trypanocide drug benznidazole. Int. J. Pharm., v.307, n.2, p.239-243, 2006.

LIN, K.H.; LIN, S.Y.; LI, M.J. Compression Forces and Amount of outer coating lier affecting the time-controlled disintegration of the compression-coated tablest prepart by direct compression with micronized ethylcellulose. $J$. Pharm. Sci., v.90, n.12, p.2005-2009, 2001.

LINDENBERG, M.; KOPP, S.; DRESSMAN, J.B. Classification of orally administered drugs on the World Health Organization Model list of Essential Medicines according to the biopharmaceutics classification system. Eur. J. Pharm. Biopharm., v.58, p.265-278, 2004.
MAARSCHALK, K.; VANDER V.; BOLHUIS, G.K. Aprimoramento das propriedades de materiais para compressão direta. Pharm. Tech. Br., v.3, n.4-8, p.17-25, 1999.

McCORMICK, D. Evoluções na compressão direta. Pharm. Tech. Br., ed. especial sólidos, p.2-12, 2005.

MSF - MÉDICOS SEM FRONTEIRAS. Desequilíbrio Fatal: ACrise em Pesquisa e Desenvolvimento de Drogas para Doenças Negligenciadas, 2001.32p. Disponível em: $<$ http://www.msf.org.br/campanha/desequilibrio.pdf $>$. Acesso em: 10 mar. 2006.

ROLIM NETO, P.J. Solubilite des constituants d'un melange de poudres et qualite des granules obtenus. Montpellier, 1992. 234p. [Tese de Doutorado. Faculte de Pharmacie. Universite de Montpellier I].

SCHOFIELD, C.J.; JANNIN, J.; SALVATELLA, R. The future of chagas disease control. Trends Parasitol., v.22, n.22, p.583-588, 2006.

SOARES-SOBRINHO， J.L.; SILVA， A.L.M.; GRANJEEIRO-JUNIOR, S.; MEDEIROS, F.P.M.; ROLIM-NETO, P.J. Desenvolvimento e validação do método analítico para o doseamento de benznidazol. Rev. Bras. Farm., v.87, n.3, p.78-80, 2006.

UNITED STATES PHARMACOPEIA. 29.ed. Rockville: United States Pharmacopeial Convention, 2006 General Information $<1174>$. v.1, p.29-747.

VIANA, O.S.; BENIGNO-JUNIOR, J.; SILVA, R.M.F.; MEDEIROS, F.P.M.; GRANGEIRO-JUNIOR, S.; ALBUQUERQUE, M.M.; ROLIM-NETO, P.J. Desenvolvimento de formulações e tecnologia de obtenção de comprimidos revestidos de efavirenz - terapia anti-HIV. Rev. Bras. Cienc. Farm., v.42, n.4,p.505-511, 2006.

WANCZINSKI, B.J.; FELIPE, D.F.; CARDOSO, M.L.C.; CAVALCANTI, O.A. Desenvolvimento de comprimidos de AAS 500 mg: influência do Amido $1500^{\circledR}$ na compressão direta. Acta Sci. Health Sci., v.24, n.4, p.649655, 2002.

Recebido para publicação em 30 de maio de 2007 Aceito para publicação em 05 de julho de 2008 